\title{
Surrounded by Spirits: Hauntings of Identity in Waimea Summer by John Dominis Holt
}

\section{Abstract:}

In 1976, John Dominis Holt published what would be considered the first novel by a Kanaka Maoli [Native Hawaiian] author in English, Waimea Summer. This coming-of-age narrative set in 1930's Hawai'i follows fourteen-year-old Mark Hull, a half White, half Kanaka Maoli boy who experiences a series of hauntings on his uncle's farm, all the while grappling with a burgeoning queer identity and conflicted cultural loyalties. In the post American-occupied Hawai'i, the teachings of Christian missionaries and anti-sodomy laws have all but eradicated the aikāne [homosexual] relationships practiced by the ali'i [royals] of Marks' genealogy, and yet the boy's queer desires refuse to die. In this paper, the novel is interpreted through Laura Westengard's theory of the queer Gothic, in which concepts of the American nuclear heterosexual family are challenged by the burgeoning past, thus returning the narrative and agency to the queer Indigenous subject.

Key words:

coming-of-age literature, Gothic fiction, Hawaiian literature, John Dominis Holt, Pacific literatures, Waimea Summer, queer theory

\section{W otoczeniu duchów. Nawiedzona tożsamość w powieści Waimea Summer Johna Dominisa Holta}

\section{Abstrakt:}

W 1976 roku John Dominis Holt opublikował Waimea Summer [Lato w Waimei], utwór uznawany za pierwszą powieść autorstwa Kanaka Maoli [rdzennego Hawajczyka] w języku angielskim. W tej narracji o dorastaniu, osadzonej na Hawajach w latach 30. XX wieku, śledzimy losy czternastoletniego Marka Hulla, w połowie białego, a w połowie Kanaka Maoli, który doświadcza serii nawiedzeń podczas pobytu na farmie należącej do wuja. Wszystko to dzieje się, gdy w chłopcu rozwija się queerowa tożsamość i narastają jego problemy z dochowaniem wierności własnej

* Alexander Casey - MA, prepares a doctoral dissertation at the Department of English of the University of Hawai'i at Mānoa (United States) on queer children's literature. Contact: ancasey@hawaii.edu. 
kulturze. Po amerykańskiej okupacji Hawajów nauki chrześcijańskich misjonarzy oraz prawna penalizacja aktów homoseksualnych doprowadziły do wykorzenienia relacji aikāne [homoseksualnych], praktykowanych przez ali'i [starszyznę] z rodu Marka, ale jego queerowe pragnienia nie wygasają. W artykule powieść zostaje zinterpretowana w odniesieniu do teorii queerowego gotyku w wersji zaproponowanej przez Laurę Westengard. W tej perspektywie przybierająca na sile przeszłość podważa wyobrażenia na temat amerykańskiej nuklearnej heteroseksualnej rodziny, a w ten sposób narracja i sprawczość zostają zwrócone queerowemu rodzimemu podmiotowi.

\section{Słowa kluczowe:}

literatura inicjacyjna, literatura gotycka, literatura hawajska, John Dominis Holt, literatury Pacyfiku, Waimea Summer [Lato w Waimei], teoria queer hough the paperback industry has profited greatly off the post-occupation, settler colonial Hawaiian fantasy (bookshelves filled with chiseled men and swooning women in hula skirts), Hawaiian literature by Kanaka Maoli ${ }^{1}$ [Native Hawaiians] has been largely overlooked in favor of settler narratives. ${ }^{2}$ In many cases, Kanaka authors have self-published or published through local presses, leading to an increase in picture books and children's literature. At the time of this essay's construction, however, only one Kanaka-written queer text has been published for children, ${ }^{3}$ yet it is the novel widely considered to be the first Kanaka novel ever written in English, John Dominis Holt's 1976 Waimea Summer: A Novel, that may mark the beginning of a queer tradition in Hawaiian writings for and about young people.

In his memoirs, Holt (1993) claims: "One by one, the old ones die and take with them the treasures of the past. All of Hawaiian life seems to slip away from us" (p. 143). Waimea Summer seems to literalise this sense of loss. This comingof-age novel follows protagonist Mark Hull, a fourteen-year-old descendant of

1 Both Kanaka and Maoli are suitable synonyms and will be used interchangeably in this essay. Additionally, because 'ōlelo Hawai' $i$ [Hawaiian language] is not considered a foreign language in Hawai'i, Hawaiian words will not be put in italics.

2 On this, Hawaiian literature scholar ku'ualoha ho'omanawanui (2017) writes: “Hawaiian literature' as an academic discipline and cultural practice has been rather obscured, suppressed alongside the language it was created from, the result of multiple layers of haole (Amer-European) colonialism and the accompanying insistence of cultural and linguistic hegemony" (p. 51).

3 Ho'onani, Hula Warrior by Heather Gale (2019) is a picture book published by Tundra Press. 
both European royalty and Hawaiian ali'i [royals], caught between the traditions of both genealogies and his first inklings of sexual desire. Mark, however, does not fall for the girls he is recommended but focuses his attention on a male farmhand, dark-skinned and unmistakably Hawaiian in all the 'traditional' ways Mark claims to despise. In a narrative grappling with issues of colorism, class, and colonial occupation, Waimea Summer turns inward, mimicking the Gothic fiction of the early United States to interrogate "the social anxieties unique to the colonial context" (Westengard, 2019, p. 11). The more Mark grapples with this identity, the more haunted his life in Waimea appears to be, and his journey of self-discovery is marred by the worry that ghosts have taken over his family's farm and are harming his young cousins. When read as a queer Gothic, Waimea Summer reflects the genre's paranoia over the breakdown of the traditional nuclear family, but rather than place the agency back in the hands of the colonial forces looking to maintain the norm, Holt gives voice to a boy haunted by the traumas of his family's past and his own fragmented sense of self.

Waimea Summer begins when Mark awakens in his uncle's rural home three days after arriving from Honolulu. From the moment he opens his eyes, the boy is "gripped by a sense of doom," feeling that all he had heard of Waimea being "ridden with ghosts and black magic seemed now to be true" (Holt, 1976/1998, p. 1). His anxieties are not unfounded: his host, the cruel and crass Uncle Fred, is set to remarry after the mysterious deaths of his previous wives; Fred's youngest son falls ill with an untraceable fever; and an akualele a flying god and fire "sent out to find victims" (p. 43) - is soon spotted in the night sky. In the American Gothic tradition, which Aldona Witkowska (2013; as cited in Skowera, 2019, p. 93) calls a "domesticated' version of the European one [...] [that] moves away from the ghosts in the castles to [...] houses and disturbed families," these themes are well-established and repeated: the dreaded 'witching hour,' the murdered wives, and the mysteriously ill and depressed child. Like it happens in many hauntings, the house in Waimea appears at first to carry the danger, but it is the occupants that prove more troublesome.

After he explores the house that third morning, Mark returns to find Julian, a dark-skinned Hawaiian farmhand, standing in his room. Julian is described as appearing "as suddenly as if from the spirit world," but he is also framed as the dark erotic Other, having "coppery skin, ebony eyes, and black beard all glistening in the flickering light" (Holt, 1976/1998, p. 3). Children's literature scholar Ebony Elizabeth Thomas (2019) calls such depictions "the dark fantastic" in which characters of colour are framed as monsters. She writes: "Fear of the monster is really a kind of desire [italics in original]. [...] the monster provides an enticement, a poisonous lure" (p. 21; Thomas refers to one out 
of seven theses on monster culture, proposed by Jeffrey Jerome Cohen, 1996). Julian, it transpires, has only come to greet the new guest and to offer help, but when Mark surmises that the farmhand may be gay (a trait in opposition to the teachings of Mark's Christian missionary ancestors, violently condemned by his uncle, and officially outlawed in 1850), the knowledge haunts him, leaving him "shaking" and "speechless" (Holt, 1976/1998, pp. 3, 68; see also Aleardo, 2013, p. 58). Julian, as a representative of both Hawaiian identity and queer desire, is Mark's first monstrous ghost.

Eve Kosofsky Sedgwick (1997; as cited in Westengard, 2019, p. 36) called this fear the "paranoid Gothic." Just as the Puritans of early America were seized by paranoia over the perceived social changes in the moral make-up of the nuclear family, the queer subject, when realising a homosexual desire in a world so heterosexually pre-described, is apt to turn that paranoia inward and attack the perceived monster of desire. Queer Gothic theorist Laura Westengard traces these fears to the British tradition, writing that "the Gothic responded to British [...] fears about race, class, gender, and sexuality" (p. 8). Mark, for his part, is fascinated with this European past, noting that his uncle's "parlor was a tribute to Victorian England" (Holt, 1976/1998, p. 9) and worrying over what his "British earl" (p. 103) ancestors might think when he dares to acknowledge his own emotions. In fact, many of the boy's ancestors noted in the text either came from or studied in England, something Mark proves far more comfortable discussing than his Hawaiian roots. He appears critical, for example, of an uncle who "did things the old-fashioned [Hawaiian] way," while another "had been trained in California and England" (p. 120). When Hawaiian relatives or customs are mentioned, they arise - like ghosts - in the past tense, titled "the old-fashioned way," a "historic relic," "da 'ole way," and "shreds of the past enter[ing] our lives" (pp. 2, 28, 90).

That Mark begins his story on the third day of his stay and notably after the witching hour has just passed ${ }^{4}$ marks the beginning of his re-emerging Hawaiian identity after what appears to be fourteen years of mostly European influences. When Julian first tells him the house is haunted, Mark reacts defensively, asking: "Was he [Julian] taunting me, a stranger from the city [...]? Was I being challenged [...] because I was [emphasis in original] fair-skinned, even though I was nearly one-half Polynesian[?]” (Holt, 1976/1998, p. 10). Mark treats his sudden awakening that fateful morning and his sense of doom as an

4 He awakens at 4 a.m., while the 'witching' or 'devil's hour' is said to be a variety of times between 3 a.m. -4 a.m. This is believed to be a taunt by evil spirits in response to the Holy Trinity (the Father, the Son, and the Holy Spirit) and Jesus Christ being crucified in the third Roman hour. 
interruption in an otherwise peaceful life, stating that "the excitement of being at last in this place [his] father had so endlessly extolled, [his] explorations around the once handsome house and garden, and exhaustion had successfully kept back the age-old sensitivity Hawaiians have to the world of spirits" (p. 1). While Mark (roughly) speaks Hawaiian and will later note that there is no White or Hawaiian 'sides' ${ }^{5}$ of his family (that is, his genealogy is not split cleanly down the middle with one White/Haole side of the family and one Hawaiian), it is clear that he is far more familiar with the beliefs of his European ancestors than his Hawaiian ones, particularly when it comes to a religious and spiritual context. Not only has he never been to Waimea before (where rests Mauna Kea, a burial ground and embodiment of many sacred Hawaiian ancestral deities), but he comes from an Episcopalian family, "among [the] Bishop[...]'s first parishioners" and was "confirmed two years ago" (p. 120) in this Christian tradition. Mark is aware of Waimea's significance but relates it immediately to Christianity, stating that "[he] had the sense that the Gods had blessed Waimea as once the God of the Old Testament had bestowed magical, extravagant beauty upon Eden" (p. 11). As for his Uncle Fred, Mark "viewed him as a historic relic: something to be treasured and admired" (p. 2). This view is at once problematic, framing Kanaka as disembodied figures of the past, while simultaneously hinting toward Mark's repressed desire to re-connect with and "treasure" his Kanaka genealogy.

If the Gothic is meant, as Westengard (2019) proposes, to invoke a "fascination with the past [...] and supernatural metaphors that work through the [...] anxieties accompanying social upheaval" (p. 8), then Holt's version serves to highlight a pivotal moment of loss in the history of Hawai' $i$. Set in the 1930s, Waimea Summer brings to light the period prior to statehood but post American occupation which Holt (1964/1995) calls "the holocaust of the $19^{\text {th }}$ century" (p. 15). He writes:

I marvel that the introduction, by foreigners, of new ideas, new laws, and new ways of doing things, could have so devastated a people so superbly organized

At a luau hosted by Uncle Fred, Mark is approached by a man who wishes to speak about family lines. He recalls many members of the boy's family as "a huge clan" and says: "Now, with the new crop, I imagine you find it hard to kept track of everyone, even among yourselves." This unknowable mix of genealogies - beyond just a Haole/Hawaiian context, a great-aunt is mentioned who "married a fellow from Shanghai" (Holt, 1976/1998, p. 118) and moved to England - undoubtedly spurred further identity confusion within young Mark, particularly as so many of the adults he meets in the novel declare him solely White while simultaneously shaming him for not being Hawaiian enough. 
[...]. But I am proud of the chiefs and people who attempted to keep order [...]. They were the victims of the historic process the human wreckage that is always left in the wake of change (p. 14).

For young Mark, these changes come not only in the form of literal human loss - the "death of eighty percent of [the Hawaiian population] [...] in one hundred years following the arrival of the first foreigners" (pp. 17-18) by Holt's estimation - but also in the form of enforced heterosexuality, Christianity, and Americanisation. The three are historically linked, tracing back to, among others, $19^{\text {th }}$-century American missionary Hiram Bingham (1855) who believed Christianity would "raise that [Hawaiian] people from their degradation and barbarism" and convert Hawaiian's "cruel superstitions, and their unbridled lusts" (p. v). In 1816, he introduced a missionary school to spread "the Gospel in heathen countries" (p. 58). The boarding school legacy would continue through the decades, and though the eventual move into Kamehameha Schools would, in time, provide an appreciation for Hawaiian tradition, the focus upon learning English and converting to Christianity remained firmly in place.

Of his time in boarding school, Holt (1964/1995) speaks of this Christian sense of morality and "stern Victorian principles" (p. 61) employed by teachers and family, but also writes that such schools were "widely known for the sexual unions which take place between young people of the same sex" (Holt, 1993, p. 191). The author is careful not to address his sexuality outright in his memoirs but moves into the neutral third person, claiming that "a boy's first ejaculation is something of an exciting or frightening experience" (p. 192) while placing the act in a communal setting with his fellow male classmates. Earlier in his recollections, he writes about a family member who "talked about sex and scandalous love affairs without the slightest inhibition," claiming "she was a true Hawaiian in this sentence” (p. 129). The paranoia that Mark experiences in Waimea Summer, therefore, appears not as a fear over a new social emergence, but the paranoia over a re-emerging and haunting past, one the boy wishes to stifle, thinking: "I cursed myself for being afraid. I cursed myself for being Hawaiian" (Holt, 1976/1998, p. 136). For Mark, the pressures to conform to new American standards are overwhelming, but as Hawaiian scholar Lilikalā Kaméeleihiwa (1992) notes: "The Hawaiian stands firmly in the present, with his back to the future, and his eyes fixed upon the past, seeking historical answers for present-day dilemmas" (p. 23). ${ }^{6}$

6 This is a common Hawaiian 'ōlelo no'eau [proverb]: "i ka wā ma mua, ka wā ma hope” [The future is in the past]. 
Prior to Christianity, Hawaiian power structures did not rest solely within the nuclear heterosexual family but included hānai [adopted] children and aikāne [queer persons], ${ }^{7}$ who were both accepted and popular amongst the ruling ali'i class (Osorio, 2018, p. 94). Kanaka scholar Mary Kawena Pukui, E. W. Haertig, and Catherine A. Lee (1972) further note that "pre-missionary homosexual practices were never 'sins' as Christianity later labeled them" (p. 109). Of Kamehameha, ${ }^{8}$ perhaps the most famous warrior and king in Hawaiian history, the sailors under British naval officer Captain Cook wrote of a man "whom he [Kamehameha] seems very fond, [...] a detestable part of [Kamehameha's] Character which he is not in the least anxious to conceal" (Morris, 1990, p. 31). Further entries recall another Hawaiian man who encountered "a handsome young fellow whose appearance he liked [...], such is the strange depravity of these Indians" (p. 33). In Waimea Summer, Mark's uncle mimics this sentiment, calling Julian "pretty primitive" (Holt, 1976/1998, p. 4). When discussing gay men and the farmhand in particular, Fred states that he "suspected that son-of-a-bitch [...]. That's why [Fred] didn't like [Julian] being in [Mark's] room!" (p. 68). Mark reacts to this condemnation with a religious connection, noting "that Fred recited as though his excoriations were prayers. He had found his Prince of Darkness in Julian" (p. 64). Such attempts to exorcise darkness and perceived ghosts fill the novel, and Mark often worries over rumors of those prayed to death ${ }^{9}$ in the process. Holt (1993), for his part, had "utter revulsion [for] the Christian activities and teaching[s]" (p. 223) a distaste that arises in many of his written works but, for the sake of his mother who "had given her life" (p. 107) to the religion, did not voice his oppositions. Mark, then, reads as a projection of this stifled discontent.

Like Holt, Mark is a descendant of Kamehameha and may share parts of his sexual identity, but he is unwilling to accept these pieces of himself. He also associates, like missionary Bingham and Uncle Fred, the 'superstitions' of

7 Osorio (2018) cites three different dictionaries with definitions ranging from " $[\mathrm{t}] \mathrm{o}$ cohabit, as male with male, or female with female" to "an intimate and trustworthy companion" (p. 94). She also notes, however, that to firmly define the word "would demonstrate a complete misunderstanding of the very nature of Kanaka Maoli aikāne relationships” (p. 49).

8 In a nightmare, Mark dreams that he "came face to face with young Kamehameha [...]. He made a lunge for [Mark's] throat” (Holt, 1976/1998, p. 47). Like Julian, Kamehameha appears both as a dangerous haunting and an embodiment of Hawaiian and queer identities.

9 This is thought to be caused by kahu 'ana'anā [sorcerers] associated with the akualele that Mark sights circling Uncle Fred's house. William K. Kikuchi (1976) asserts that "fireballs seen at one's residence indicate disharmony" (p. 165) which seems apt to Mark's internal struggle. 
the Hawaiians with the farmhand Julian. Unlike Uncle Fred, Mark approaches Julian with a queer attraction that becomes greatly conflated with his religious crisis. When Julian comes to the house to help his sick cousin, Puna, Mark considers his Hawaiian practices of healing and praying to be evil, for they "conflict with his Christian upbringing and missionary heritage, both the British [...] and the white American past" (Najita, 2001, p. 179). In this sense, Julian embodies all that Bingham hoped to eradicate.

Mark repeatedly demonstrates both disapproval of and desire for Julian. At Uncle Fred's luau, the boy watches Julian dance with a woman and claims that "a pagan air, lingering on from earlier days, seemed to surround [Mark, Julian, and the woman]. [They] [...] were really phantoms skittering perilously close to the outer edges of reality in [their] play" (Holt, 1976/1998, p. 95). Mark, in a jealous attempt to catch Julian's attention, positions himself within a group of girls to assure he remains in Julian's line of sight. His allusions to a "pagan air," indicating that which is incompatible with the morals of Christianity, and his self-identification as a phantom, are at once self-critical and exemplary of Mark's burgeoning identity outside of the Christian expectations he has tried thus far to fulfill. That Mark calls this a "play" also suggests a sort of posturing that is further emphasised when, later, Mark experiences his first sexual encounter with a woman.

Kimiko, the "picture bride" (Holt, 1976/1998, p. 152) of a Japanese man Mark comes to visit and a woman whose rape by a drunken guest he stops, leads the boy away from the other men, and to please her he "assumed her position, as best as [he] could" (p. 156). This mimicking - the desire to be what she expects of him - is expounded when the woman, after undressing Mark, "turned back, holding masks" (p. 156). Mark accepts his "with misgivings" but notes that these feelings were not "about what mana or signs it contained" (p. 156). Mana [power, life force] is discussed frequently by the characters in the preceding pages, particularly when Mark receives a pair of spurs once belonging to a dead man. Mark reacts with a Western superstition and fear but is assured that they should have good mana and that bad mana can be exorcised (p. 138). He also learns that there is mana ${ }^{10}$ in all things, something Holt (1964/1995) notes in his essay On Being Hawaiian: "We are links to the ancients: connected by inheritance to their mana [...] respecting all things of

10 Mana stretches well beyond Holt or Mark; it is a key Hawaiian cultural concept, defined by Pukui, Haertig, and Lee (1972) as a "characteristic [that] brought high regard to men and women [...]: supernaturally bestowed power [...], the specialized talent that was also the gift of the gods" (p. 296). 
the earth, including rocks and dirt as living things related somehow through a cosmic connection to ourselves" (p. 7). Mark does not expand on what about the masks gives him pause, but if it is not the mana or appearance of the masks that worry him, his "misgivings" seem instead to indicate a deeper discomfort and personal confusion. He accepts the encounter but the next morning feels "waves of gloating, embarrassment, and shame" and rides his horse away at top speed, for "the panic was on [him] again" (Holt, 1976/1998, p. 157, 160). This, Westengard (2019) calls the Gothic queer's ability to resist "narratives of wholeness and progress," a way of understanding the text and Mark's confusing, conflicting reactions that avoids "conceptual binaries, and gives voice to innumerable experiences of queer insidious trauma" (p. 20). The problematic nature of the teenager's first sexual encounter - both in its paedophilia and the trauma Kimiko reacts to moments before - are beyond the scope of this paper, but it seems clear that both characters attempt to escape, albeit temporarily, the potentially dangerous sexuality of men. For Kimiko, Mark provides a nonthreatening intimacy; for Mark, she is an initiation into the heterosexual world in which he feels obligated to conform.

The continued pressures Mark faces to choose a female companion are frequent and reflective of Westengard's "conceptual binary" and queer trauma. Mark is told by his Uncle Fred, just before arriving at Kimiko's home, that if he were the boy's "age [he would] have found [his] way here a long time ago. Have you [Mark] seen those beautiful girls?” (Holt, 1976/1998, p. 147). Uncle Fred often questions his nephew's lack of interest in female companions, until Mark begins to worry himself, noticing that he does not understand sexual allusions to women, nor does he feel the desire he knows he is supposed to. Instead, the boy reacts in ways his uncle cannot approve of; the morning after he leaves Kimiko, Mark assists one of the other men he travels with and is told: "[If] you was one wahine [girl], Markie, I geeve you one keez [kiss] now!," to which the teenager, turning his cheek, responds, "Kiss me anyhow." Both men notably "fell silent" (p. 159) when Uncle Fred reappeared. Later, when Mark meets Mr. Hanohano, a man who tries to cure him of his fear of ghosts, he calls him "an older family-edition of Julian" and reacts to the men Mr. Hanohano goes to meet by "let[ting] [his] eyes wander. There was so much to please them" (p. 171). The two swim naked in the ocean, where Mark "ran yelling like a savage into the pounding surf" (p. 178). This self-degradation is paired with a rare moment in which he allows himself to feel unrestrained, a reaction in opposition to his previous assertion that to openly express his emotions was to be 'too Hawaiian,' something he gathered "from the perspective of the judge, the British earl, and the American missionary, [his] haole ancestors" (p. 103). Pacific literature 
scholar Paul Lyons (2018) calls this "sensation of being beside oneself" one that "produces uncanniness and panic" (p. 106) and indeed, when Mark says goodbye to the man, he sinks his "nose into his chest muscles and drank in the smell of the sea" and then pulls away, claiming that "memory of the early morning intimacy at the beach made [him] tremble" (Holt, 1976/1998, p. 181). This is not the first time Mark has struggled to accept the many facets of his identity - both leaning into his desires and isolating himself from their possibilities. This may reflect Holt's personal fears from his boarding school experience that Hawaiian children would internalise anti-Hawaiian sentiment; it is also likely side-effect of the early American pressures (and laws) to stifle queer desire.

This sort of "conflict and fragmentations within the Maoli community," according to Lyons (2018), is a "result from displacement and internalized thought" that stems from how people "relate to or are alienated from the 'aina" (p. 102). Holt, therefore, "links attacks on queer subjectivities directly to paternalism, domestic abuse, and alcoholism, and to in-community racism between lighter and darker complexioned Hawaiians" (p. 102). As was true with Julian, Mr. Hanohano is darker-skinned, as opposed to Mark's own fair complexion, and he is well-versed in Hawaiian tradition; he also brings the boy into the ocean, reconnecting him with the natural world and reminding him, as the novel's author himself asserted in his memoirs, that "[m]ana is spirit. It's the life force," and that even rocks "are alive in their own way" (Holt, 1976/1998, p. 176). Most importantly, Mr. Hanohano tells Mark, “[p]eople don't believe in spirits here, Sonny. They live [emphasis in original] with them" (p. 172). The fear of ghosts, therefore - though attributed throughout the novel to 'Hawaiian superstition' - is painted as an American imposition. In Hawaiian belief, while the messages or warnings they bring can be frightening, ghosts themselves are not to be feared; they are 'aumākua [ancestors] (Pukui, Haertig, \& Lee, 1972, p. 39). The 'aumākua are also "judge and jury after death," however, and for Mark, as is the case for many with a conflicted soul, the possibility of judgement is too great a risk; already under the threat of Christian hell fire, the possibility of believing in and possibly failing another set of ancestors ${ }^{11}$ and deities is too much for the teen to face (p. 40). The 'ghosts' that truly haunt Mark, then, are

11 Though it is not said outright, given Holt's own feelings on the subject and Mark's disposition, it is possible he is also overwhelmed by what might be referred to as 'White guilt.' Throughout the novel, Mark becomes violently ill, tearful, or terrified whenever violence occurs around him, even in situations deemed quite ordinary, such as the killing of a goat which those in Waimea claim to do "every week" (Holt, 1976/1998, p. 14). Knowledge of the violent Hawaiian genocide by European arrivals, then, is likely a terrifying haunting for Mark in of itself. 
the possibilities of an identity beyond that which he has already comfortably accepted. "Many strange things did go on in Hawaiian families where the mixture of blood and heritage divided one in two," he notes, "causing people - much to their own distress - to combine both defiance and acceptance of the old beliefs" (Holt, 1976/1998, p. 21). The more Mark defies these 'old beliefs' - particularly as it relates to queer intimacy - the more the possibilities haunt him.

Lyons (2018), however, is careful to note that "binaries [...] are shown to be inadequate" (p. 101) in Holt's work, and that this is "not about confusion, but about coming to terms with the somatic effects and historical sources of confusion" (p. 105). Mark, as a fourteen-year-old, White-appearing biracial boy on his path to self-discovery, is steeped in contradictions and confusions, but this does not mean that Holt has declared this divide incompatible. In fact, near the end of the novel, Mark is wrongfully assumed to be purely "from the haole side" of his family and responds that "there is no haole side" (p. 170), suggesting that his family lines are not so divisively split. Further, Kanaka understanding of genealogy "does not consider blood quantum" (ho'omanawanui, 2017, p. 53). Holt (1993) is transparent in admitting temptations to forget his Hawaiian roots, that "this glittering world [of European literature] intrigued [him] to the point where [he] became alienated from Hawai'i" (p. 231) and that "for many good reasons, some of [Kanaka Maoli] are satisfied to forget [their] ethnic roots, and [...] [be] good, productive citizens: Americans, in spite of [their] color or [their] cultural heritage," (p. 13) but he also proudly asserts his Hawaiian identity, adding that this self-questioning is part of the process. He writes: "They say we dwell too much on the sentimental and romantic aspects of our past. They say that we have too much pride, and not enough get-up-and-go [...] but what do we think of ourselves?" (p. 19).

This is not a question Holt answers, nor does Mark. The boy eventually leaves the island, leaves Julian and Mr. Hanohano, leaves the land and a history he has yet to fully understand. Before embarking, however, he stops at a sacred site and is confronted by an old man who serves as its protector. Here, according to the old man, rests "the stone of Kamehameha" who he calls "the Great One, the Lonely one" and who was known to fight sharks by "run[ning] down the hill and into the waters." Though the man claims that "to some [the sharks] are loving and mindful. They protect those who are theirs," Mark reacts to the sight of sharks in the water below with great fear, indicating further that he does not yet feel that he is "theirs" (Holt, 1976/1998, p. 193). As Mark continues to speak with the old man, the ghosts he has faced all summer become literal, materialising as chiefs of the heiau [religious temple] flanked by wooden sculptures of "angry, protective deities" (p. 194). The old man cries out to Mark, 
"Stay! You belong to us," but Mark, like Kamehameha, "run[s] pell-mell down the hillside" (p. 195). The boy, however, runs to avoid his ancestors, not to face them. ${ }^{12}$ This last line fails to present any definitive closure to his story, but such a neat conclusion cannot be expected of the genre, for "Gothicism emerges as a slippery, shadowy rhetoric [...] [for] those traumatic experiences that tend to dissipate before our eyes and slip from our grasp" (Westengard, 2019, p. 63).

The lack of an idealised ending (one in which Mark comes to embrace all aspects of his identity), however, has led to questions over Holt's motives. With its status as the first known Kanaka authored novel in English, Waimea Summer is positioned under tremendous pressure, expected both to honour a Kanaka identity and to present Hawai' $i$ to the world, as is the unfortunate fate of underrepresented peoples in literature: to be, at once, every story of every Hawaiian. ${ }^{13}$ Yet, Holt's (1964/1995) writings, in which he fears for the "loss of Hawaiianess" due to the information "that came to us [...] garbled or deliberately distorted" (p. 7), show his determination to explore but not provide a definitive answer on what it means to be Hawaiian. Holt has instead taken on the role of investigator, a role he then lends to Mark. The boy "is identified as a keeper of mo'olelo [stories] [...] who is, therefore, more sensitive to the ancestral" (McDougall, 2011, p. 124). Mark is not a spokesperson for Hawaiian identity but a story collector. It is a common Hawaiian saying: "A' pau ka 'ike i ka hālau ho'okahi" [Not all knowledge is contained in one school (as translated by ku'ualoha ho'omanawanui, 2017, p. 53)] and throughout the novel, Mark ventures through many schools - for better or for worse.

If Holt's goal is not to provide a single narrative for the Hawaiian experience, perhaps it is to illuminate the uphill battle faced by Hawaiian youth, particularly those of mixed race, and to suggest a multitude of ways in which one can 'be Hawaiian.' In his essay of that name, On Being Hawaiian, ${ }^{14}$ which he describes as coming "out of [him] like an anguished child," Holt (1964/1995) states, "I see scores of handsome children who will grow up to be less the victims of their heritage than I and my generation [...] less bound to the fragmented, but imposingly powerful image of the past" (p. 20). Waimea Summer, set in the 1930s but published in 1976, suggests that Holt, while asking us to look

12 The story the old man tells here is of the shark Keoua Kuahuula, "one of [Kamehameha's] most hated enemies" (Holt, 1976/1998, p. 194) but some sharks are considered to be aumākua, or ancestors sent in animal form to protect family.

13 See Chimamanda Ngozi Adichie’s (2009) “The Danger of a Single Story."

14 This essay, denied publication by the Honolulu Advertiser, was self-published. Holt then created two presses in Hawai' $\mathrm{i}$ : the Topgallant Press in 1964 and Ku Pa'a press in the early 1990s (McDougal, 2011, p. 121). 
back, calls with hope upon the 'ōlelo no'eau [proverb]: “i ka wa ma mua, ka wa ma hope" [The future is in the past] (Lyons, 2018, p. 95). Reading queer Hawaiian identity as a ghost in Waimea Summer suggests that, despite great efforts by colonial forces, queer Kanaka refuse to stay locked in the past, to be silenced. When, decades later, Hawaiian representation still takes the form of a historical long-before, as exemplified by the newest Disney attempt at 'diversity' via the film Moana (Shurer, Clements, Musker, 2016), seeing Hawai'i as a thriving nation of the present remains vitally important.

With one published children's queer Kanaka text now on the market (as of late 2019), there is hope that Holt's optimism for those "scores of handsome children" will come to fruition, but for Mark (and, by extension, Holt), identity, both queer and racial, remains an elusive specter - an ever present haunting of a life "less [...] fragmented" (Holt, 1964/1995, p. 20) and just out of reach.

\section{References}

Aleardo, Z. (2013). Sodomy laws and gender variance in Tahiti and Hawai'i. Laws, 2(2), 51-68. https://doi.org/10.3390/laws2020051.

Bingham, H. (1855). A residence of twenty-one years in the Sandwich islands; or the civil, religious, and political history of those islands: Comprising a particular view of the missionary operations connected with the introduction and progress of Christianity and civilization among the Hawaiian people: Third edition revised and corrected. To which is added a table of missionaries of the American board to the Sandwich islands. Canandaigua, NY: H. D. Goodwin.

Cohen, J. J. (1996). Monster culture (seven theses). In J. J. Cohen (Ed.), Monster theory: Reading culture (pp. 3-25). Minneapolis, MN: University of Minnesota Press.

Gale, H. (2019). Hoonani, hula warrior. Toronto: Tundra Books.

ho'omanawanui, k. (2017). A cairn of stories: Establishing a foundation of Hawaiian literature / He ahu mo'olelo: e ho'okahua i ka paepae mo'olelo Palapala Hawai'i. Palapala, 1, 51+.

Holt, J. (1993). Recollections: Memoirs of John Dominis Holt 1919-1935. Honolulu, HI: Ku Páa.

Holt, J. (1995). On being Hawaiian. Honolulu, HI: Ku Paa. (Original work published 1964).

Holt, J. (1998). Waimea summer: A novel. Honolulu, HI: Ku Páa. (Original work published 1976).

Kame'eleihiwa, L. (1992). Native land and foreign desires. Honolulu, HI: Bishop Museum. 
Kikuchi, W. K. (1976). The fireball in Hawaiian folklore. In A. L. Kaeppler \& H. A. Nimmo, Directions in Pacific traditional literature: Essays in honor of Katharine Luomala (pp. 157-172). Honolulu, HI: Bishop Museum.

Lyons, P. (2018). John Dominis Holt’s Kanaka Maoli modernism. Symploke, 26(1), 93-108.

McDougall, B. (2011). 'O ka lipo o ka lā, 'O ka lipo o ka pō: Cosmogonic kaona in contemporary Kanaka Maoli literature. Unpublished PhD thesis, Department of English, University of Hawai'i at Mānoa, Mānoa, USA. Retrieved from https:// scholarspace.manoa.hawaii.edu/handle/10125/101627.

Morris, R. (1990). Aikāne: Accounts of Hawaiian same-sex relationships in the journals of Captain Cook's Third Voyage (1776-80). Journal of Homosexuality, 19(4), 21-54. https://doi.org/10.1300/J082v19n04_03.

Najita, S. (2001). History, trauma, and the discursive construction of 'race' in John Dominis Holt's Waimea Summer. Cultural Critique, 47(1), 167-214. https://doi. org/10.1353/cul.2001.0026.

Ngozi Adichie, C. (2009, July). The danger of a single story [Video file]. Retrieved from https://www.ted.com/talks/chimamanda_ngozi_adichie_the_danger_of_a_single_story.

Osorio, J. H. (2018). (Re)membering 'upena of intimacies: A Kanaka Maoli mo'olelo beyond queer theory. Unpublished PhD thesis, Department of English, University of Hawai'i at Mānoa, Mānoa, USA. Retrieved from https://scholarspace.manoa. hawaii.edu/handle/10125/62423.

Pukui, M. K., Haertig, E. W, \& Lee, C. A. (1972). Nānā i ke kumu (look to the source) (vol. 2). Honolulu, HI: Hui Hānai.

Sedgwick, E. K. (1997). Paranoid reading and reparative reading; or, you're so paranoid, you probably think this introduction is about you. In E. K. Sedgwick (Ed.), Novel gazing: Queer readings in fiction (pp. 1-37). Durham, NC: Duke University Press.

Shurer, O. (Producer), Clements, R., \& Musker, J. (Directors). (2016). Moana [Motion picture]. United States: Walt Disney Studios Motion Pictures.

Skowera, M. (2019). Lewis Barnavelt and the rainbow over New Zebedee: Queering The House with a Clock in Its Walls. Dziecinstwo. Literatura i Kultura, 1(1), 85-108. https://doi.org/10.32798/dlk.29.

Thomas, E. E. (2019). The dark fantastic: Race and the imagination from Harry Potter to the Hunger Games. New York, NY: New York University Press.

Westengard, L. (2019). Gothic queer culture: Marginalized communities and the ghosts of insidious trauma. Lincoln, NE: University of Nebraska Press.

Witkowska, A. (2013). American Gothic, czyli horror amerykańskiego domostwa. Analiza „udomowionej”, amerykańskiej wersji gotyku na przykładzie seriali American Gothic i American Horror Story. Media - Kultura - Komunikacja Społeczna, 9, 154-162. 